\title{
Resenha
}

\section{O BRASIL E A QUESTÃO JUDAICA: IMIGRAÇÃO, DIPLOMACIA \\ E PRECONCEITO, de Jeffrey Lesser}

(Rio de Janeiro: Imago, 1995, p. 371).

René E. Gertz*

Jeffrey Lesser resenhou meu livrinho $O$ perigo alemão (The Americas, v. 50, n. 1, julho de 1993, p. 141-142), apesar de não ser especialista em imigração alemã. Da mesma forma eu me sinto em condições para fazer um rápido comentário sobre seu $O$ Brasil e a questão judaica, apesar de não ser especialista em imigração judaica. É que em ambos os textos, apesar de diferenças, há elementos comuns.

Quanto às diferenças, uma delas está na ampla fundamentação documental do trabalho de Lesser, enquanto o meu carece em grande parte da indicação das fontes em que baseio minhas conclusỏes, o que tem a ver com o tipo de livro em que meu texto foi publicado. A crítica que Lesser formula nesse sentido é perfeitamente justa. Além dessa diferença formal, há diferenças no conteúdo em si. Enquanto a "questão alemã" (o "perigo alemão") tem, no Brasil, uma longa tradição de mais de 150 anos, a "questão judaica" aparece somente em torno de 1930,

- Professor do Departamento de História da PUCRS. 
como o autor mostra no primeiro capítulo. Uma segunda diferença está no fato de que, apesar de ser um fenômeno mais recente, os preconceitos e a resistência à presença de imigrantes judeus e descendentes com certeza foram, no conjunto, bastante mais fortes do que em relação a alemães e descendentes, ao menos no período anterior ao Estado Novo. Afinal, no que tange aos alemães tratava-se da conspiração de apenas um país (a Alemanha) contra a pátria brasileira; no que tange aos judeus a tradição anti-semita tinha uma história secular a nível internacional e baseava-se no pressuposto de uma conspiração planetária contra a pátria brasileira e todas as outras pátrias.

O que merece destaque maior, porém, são justamente as semelhanças, e essas apontam para a clara necessidade de revisão de algumas teses sobre a cordialidade, a tolerância, o caráter plural e ecumênico da sociedade brasileira, e sobretudo de suas elites - e isso não só em relação à população negra. Lesser mostra as crescentes restrições à imigração judaica a partir de 1930, destacando a presença maciça de preconceitos de toda ordem. Juntamente com $O$ anti-semitismo na era Vargas de Maria Luíza Tucci Carneiro (São Paulo, Brasiliense, 1988) - com o qual certamente mantém algumas diferenças - evidencia que o anti-semitismo não estava restrito a algumas figuras, dentre as quais sobressai Gustavo Barroso, e que o defendiam de forma aberta, mas que ele se encontrava de forma menos explícita, porém atuante, profundamente enraizado na elite brasileira.

Creio, porém, que a semelhança mais importante entre minhas análises sobre o "perigo alemão" e as de Lesser sobre a "questão judaica" está na constatação de uma profunda ambivalência da elite brasileira e que muitas vezes, a posteriori, serviu para difundir a idéia de uma ampla tolerância e democracia. Alemães eram considerados bons para o desenvolvimento do Brasil e até para o "branqueamento" da raça, mas eram vistos como péssimos cidadãos, inassimiláveis, pouco leais à nova pátria, um perigo para a nacionalidade. Lesser insiste em várias passagens do livro sobre esse ponto no que tange aos judeus: "... conforme argumento no decorrer deste trabalho, tanto as noções de filo como anti-semitas são, com freqüência, mantidas de forma simultânea, pois muitos brasileiros que descreveram os grupos étnicos e raciais de forma estereotipada freqüentemente associavam noções tanto positivas quanto negativas" (p. 31). "Os relatos da imprensa sobre a abertura da colônia [judaica de Resende, no Rio de Janeiro] estavam repletos de imagens confusas sobre os judeus. Na maioria dos casos, porém, esses relatos refletiam uma visão 
de que 'os judeus' eram simultaneamente positivos para o desenvolvimento e negativos para a sociedade brasileira" (p. 164). "A tensão entre as imagens anti-semitas tradicionais e os novos julgamentos positivos acerca dos judeus levou alguns formuladores políticos a se colocarem simultaneamente a favor e contra a imigração judaica" (p. 223).

Nesse sentido o livro de Lesser traz uma importante contribuição para o estudo do "caráter nacional brasileiro", analisado à mão de farta documentação sobre a "questão judaica". $\mathrm{Na}$ "orelha" do livro Boris Fausto, no entanto, ainda aponta para a sua importância como contribuição para os estudos da história da imigração no Brasil. Nos últimos anos surgiram alguns trabalhos importantes sobre a imigração "não-clássica" da década de 1930/40. Gostaria de destacar apenas Exil in Brasilien. Die deutschsprachige Emigration 1933-1945 (Leipzig, Die Deutsche Bibliothek, 1994) e o livro de Izabel Maria Furtado Kestler sobre o exílio e a literatura do exílio de autores de língua alemã (Die Exilliteratur und das Exil der deutschsprachigen Schriftsteller und Publizisten in Brasilien. Frankfurt/M, Peter Lang, 1992). O livro em questão e outros trabalhos de Lesser contribuem com significativos acréscimos para o conhecimento e a compreensão da importância desses imigrantes para o Brasil.

Gostaria de fazer ao menos uma (auto)crítica, para encerrar. Ao lidar com temas dessa natureza corremos o sério risco de, ao criticar os preconceitos dos outros, nós mesmos incorrermos em erros derivados de preconceitos. Em no mínimo duas passagens do livro Lesser afirma que o integralismo foi "parcialmente financiado pela embaixada alemã" (p. 112 e 307). Aparentemente o autor se baseia em Robert Levine e Edgard Carone para fazer essa afirmação (nota 57, p. 145). Esses dois autores, no entanto, não reproduzem mais do que o senso comum e não apresentam provas de suas afirmações. O que está provado é que os integralistas teriam apreciado muito uma ajuda alemã, mas a pesquisa histórica ainda precisa provar que a Alemanha nazista realmente correspondeu a esse desejo. 